\title{
Assessment of Paint Layers Quality 3. Analysis by SEM-EDAX and XRF techniques of the paint layers applied on a railway bridge
}

\begin{abstract}
IOSIF LINGVAY ${ }^{1}$, ADRIANA MARIANA BORS'2*, VIRGIL MARINESCU ${ }^{1}$, SORINA MITREA ${ }^{1}$, EMESE VARGA ${ }^{3}$
1.National Institute for Research and Development in Electrical Engineering INCDIE ICPE-CA, 313, Splaiul Unirii, 030138, Bucharest, Romania

2.ICPE SA, 313 Splaiul Unirii, 030138, Bucharest, Romania

3.Hungarian Railways Co., Regional Infrastructure Directorate of Szeged, Regional Management Support, 6720 Szeged, Tisza Lajos krt. 28-30, Hungary

In order to identify the premature biodegradation causes of paint applied in 2013 on a railway bridge, top coat layers applied have been investigated by XRF and SEM-EDAX techniques after 32 years, corresponding to periods of operation under identical climatic conditions of 4.5 years and 3.5 years respectively. By analysis of the experimental results obtained, it has been found that by using suitable painting materials (titanium content of about $7.5 \%$ - TiO for UV protection) an exploitation period of more than 30 years could be obtained. Low-carbon (low polymer) and titanium dyeing materials with significant content of soluble salts have a low durability and anticorrosive protection capability. They degrade relatively fast both by top coat degradation and by intense increases of biofouling.
\end{abstract}

Keywords: paint coat, SEM-EDAX, XRF, railway bridge, biodeterioration

The metal structures durability and safety in exploitation are complex issues from theoretical point of view, but also with material, social and, ecological significant implications.

The theoretical complexity of the issues arises from the special diversity of the stress factors acting synergistically on the metal structures and the protection systems provided.

Depending on the operating environment during exploitation, the metal structures and the anti-corrosion protection systems with which they are provided are exposed to a number of stress factors such as: mechanical (vibration, trepidation, etc.), thermal [1, 2] climatic [3-6], non-ionizing radiation in IR and / or UV spectrum $[2,4,6$, 7], chemical [8-12], microbiological [14-25] etc.

Under concerted / simultaneous and synergistic action of stress factors, corrosion protection films (usually polymeric) are ageing and lose their anti-corrosion protection capability [15].

After the first corrosion germs appear under the paint layer the process is substantially accelerated - firstly in the joining zones (screws, welds, etc., fig. 1 and fig. 2), mechanical stress concentrators [26], which causes the metal structure to crash/ to collapse, to additional stresses $[26,27]$.

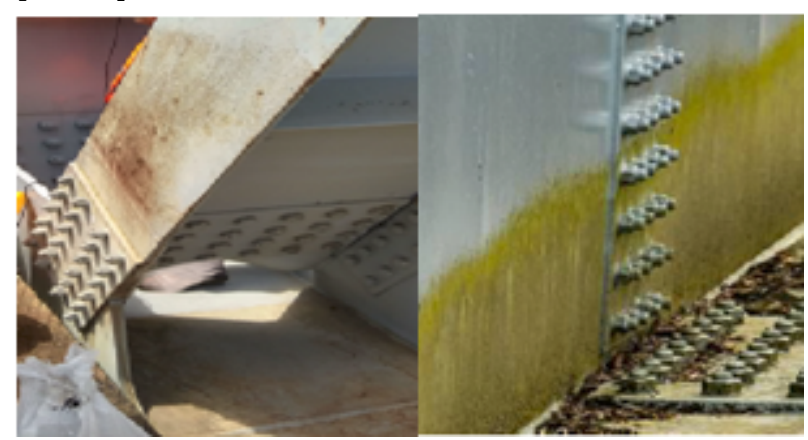

Fig. 1. The paint layers degradation at joints of a railway bridge [23]
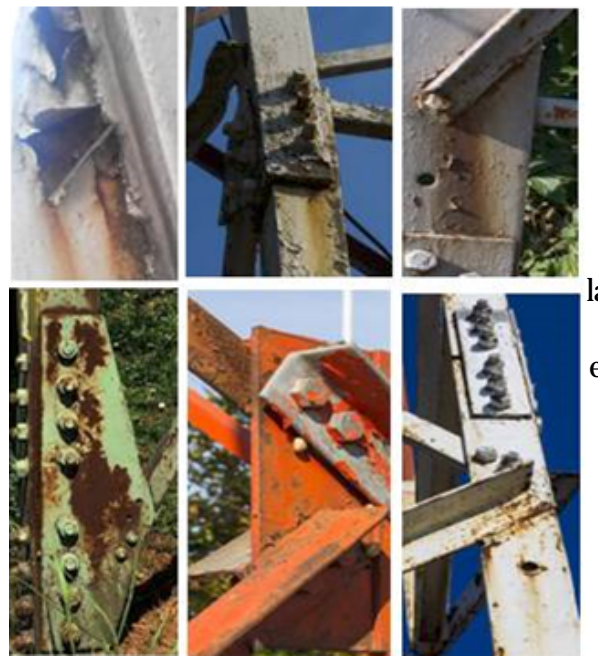

Fig. 2. The paint ayers degradation at the joints of an electric line support pillar - local corrosion cell formation [26]

Recent studies show that the behaviour of microorganisms [32-37], in ELF [28-31] electric fields of anthropogenic origin is changed, and respectively is stimulated the growth and multiplication of molds [38], which leads to increasing the speed of biodegradation of polymers [15-21, 39, 40] and of metal corrosion [41-48].

The common painting materials used to protect metal structures are polymers based composites with the addition of various ingredients / fillers (usually inorganic) and pigments (of colour).

When applying paint layers, optimum viscosity is ensured by the addition of various organic solvents - which evaporate during the paint layer polymerisation (disperse in air - with all the environmental consequences [49-51]).

The structure and thermal stability of the polymer largely determine the resistance to action of microbiological factors.

The content of soluble mineral salts of the used additives decreases moisture resistance and favours the mold growth (provides the mineral salts necessary for growth and multiplication). Large differences in the behaviour and

*email: adrianambors@gmail.com; Phone: +40773917319 
durability of painting materials applied on different sections of a railway bridge (i.e. exposed to identical climatic conditions) have recently been reported [23], and only on one of the recently repainted sections excessive growths of biofouling were found, including molds, algae, moss and lichens [24].

In view of these considerations, the paper aim is to analyse, by the SEM-EDAX and XRF techniques of the paint samples taken from of the third section of bridge presented in [23] to identify the premature biodegradation causes of paint applied in 2013 and to identify the top coat constituents that favoured the growth of biofouling.

\section{Experimental part}

From the three sectors of the bridge presented in [23] repainted in 2014 (the Western sector), samples of painting material were taken. Samples were analysed by SEM-EDAX and XRF techniques. SEM-EDAX determinations were performed with INCA Energy 250 energy dispersive spectrometer (EDS) - Oxford Instruments belonging Auriga (Zeiss) field emission scanning electron microscope (FESEM). XRF determinations were performed on a S8 TIGER spectrometer from Bruker -Germany).

\section{Results and discussions}

The comparative determinations results obtained by the XRF technique are summarized in table 1.

Analyzing the data in table 1 it is observed that in samples taken from the Eastern section were identified appreciable amounts of chlorine, phosphorus and potassium respectively. An explanation for this presence could be the origin / quality of the additive material used to achieve the paint, respectively its impurities.

This explanation is also supported by the relatively high content of silicon, which suggests that the inorganic filler material (probably barium sulphate) used to achieve the paint applied to the Eastern section was from a mineral source with appreciable impurities of chlorides, phosphates and silicates. The appreciable content of chlorine, phosphorus and potassium (which give lightly soluble salts) of the paint used on the Eastern section can explain both the massive biofouling increases and the substantially lower resistivity of the coating layer on this section (reported in [23]).

Probably these elements have ensured the mineral salts need for growth and multiplication of the identified and reported microorganisms in $[23,24]$.

The presence of lead in the sample taken from the central section is explained by the use of primer based on lead used for painting in 1986. SEM images representative of paint samples taken from the field are shown in figures 3-5.

By comparative analysis of the figures $3-5$, it is observed that the morphostructural structure investigated of the paint samples differs depending of the sampling site, respectively the painting material quality and the exposure duration of the paint layers to the specific stress factors of the operating conditions. The paint applied in 2014 (fig. 5) has a continuous, evenness appearance in which dust particles of the addition material are distinguished, unlike the paint applied in 2013 (fig. 3) which shows numerous cracks / fractures and pronounced unevenness. Thus, the biofouling fixation reported in [23] can be explained.

XRF DETERMINATION RESULTS

\begin{tabular}{|c|c|c|c|c|}
\hline \multirow{2}{*}{$\begin{array}{l}\text { Element } \\
\text { identified }\end{array}$} & \multirow{2}{*}{$\begin{array}{l}\text { Atomic } \\
\text { number }\end{array}$} & \multicolumn{3}{|c|}{ Content $[\%]$ according to location of sampling } \\
\hline & & $\begin{array}{l}\text { Western section } \\
\text { (painted in 2014)) }\end{array}$ & $\begin{array}{l}\text { Center section } \\
\text { (painted in 1986) }\end{array}$ & \begin{tabular}{|l} 
East section \\
(painted in 2013)
\end{tabular} \\
\hline$\overline{B a}$ & 56 & 2.51 & 0.98 & 4.35 \\
\hline $\mathrm{Ca}$ & 20 & 0.46 & 0.05 & 1.05 \\
\hline$T i$ & 22 & 1.28 & 5.27 & 0.75 \\
\hline$S$ & 16 & 0.54 & 0.34 & 0.82 \\
\hline $\mathrm{Fe}$ & 26 & 0.09 & 0.01 & 0.37 \\
\hline$Z n$ & 30 & 0.19 & 0.41 & 0.15 \\
\hline Sr & 38 & $54 \mathrm{ppm}$ & $61 \mathrm{ppm}$ & 0.05 \\
\hline $\mathrm{Cl}$ & 17 & - & - & 0.19 \\
\hline$P$ & 15 & - & - & 0.12 \\
\hline$K$ & 19 & - & - & 0.04 \\
\hline $\mathrm{Si}$ & 14 & 0.01 & 0.04 & 0.39 \\
\hline$P b$ & 82 & - & 0.17 & - \\
\hline
\end{tabular}

*Differences up to $100 \%$ are organic matrix (polymer) and non-identifiable elements by XRF (with atomic number <11)
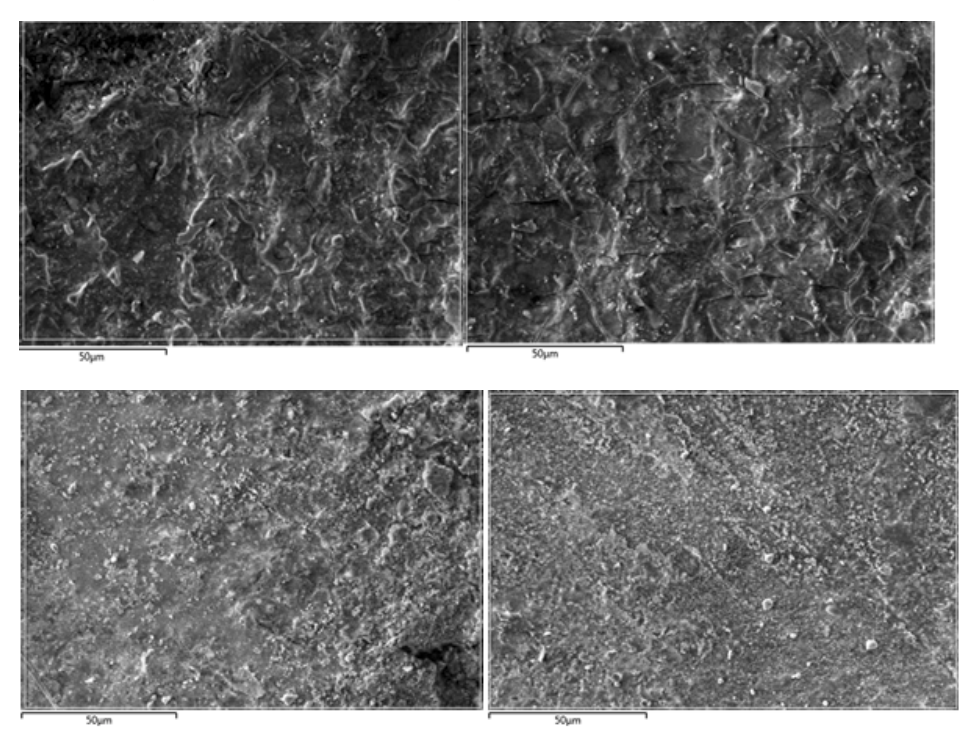

Fig. 3. SEM images representative of the paint samples taken from the Eastern section of bridge

Fig. 4. SEM images representative of the paint samples taken from the central section of bridge 

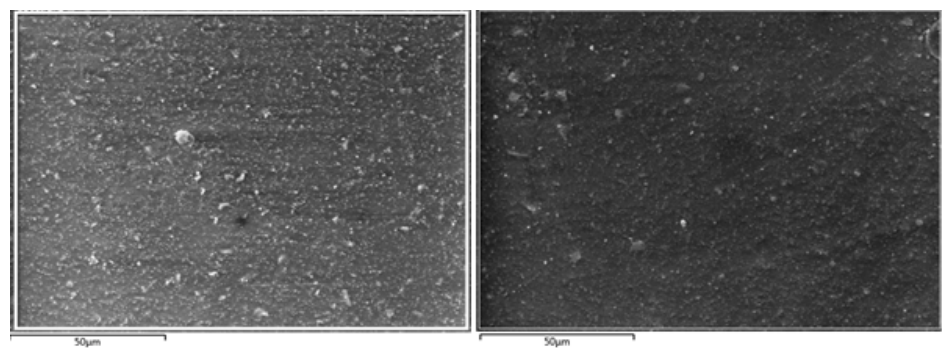

Fig. 5. SEM images representative of the paint samples taken from the Western section of bridge

The paint applied in 1986 (fig. 4) has the specific appearance of a coating layer exhibited for a long time (32 years) by atmospheric weathering and solar radiation, respectively, with a continuous appearance (without cracks) but with slight unevenness due to ageing and chalking of the polymer.

The representative EDAX spectra recorded in various positions / areas located on the surface of the investigated paint samples are shown in figures 6-8.

Comparative analysis of EDAX spectra obtained in various positions / areas located on the surface revealed compositional differences (explained by the low volume of investigated material of approximately $3.5 \times 3.5 \mu \mathrm{m}$ area on a depth of up to $1 \mu \mathrm{m}$, i.e. below $12.5 \mu \mathrm{m}^{3}$ ).

Under these conditions, EDAX spectra were recorded in 10 different positions and percentages of the obtained media for evaluation aim as accurately as possible of the compositions on the paint layers surface investigated on each sample.

Normalized recorded average results (excluding nonidentifiable elements by EDAX, or elements with an atomic number less than 5 ) are presented in table 2.
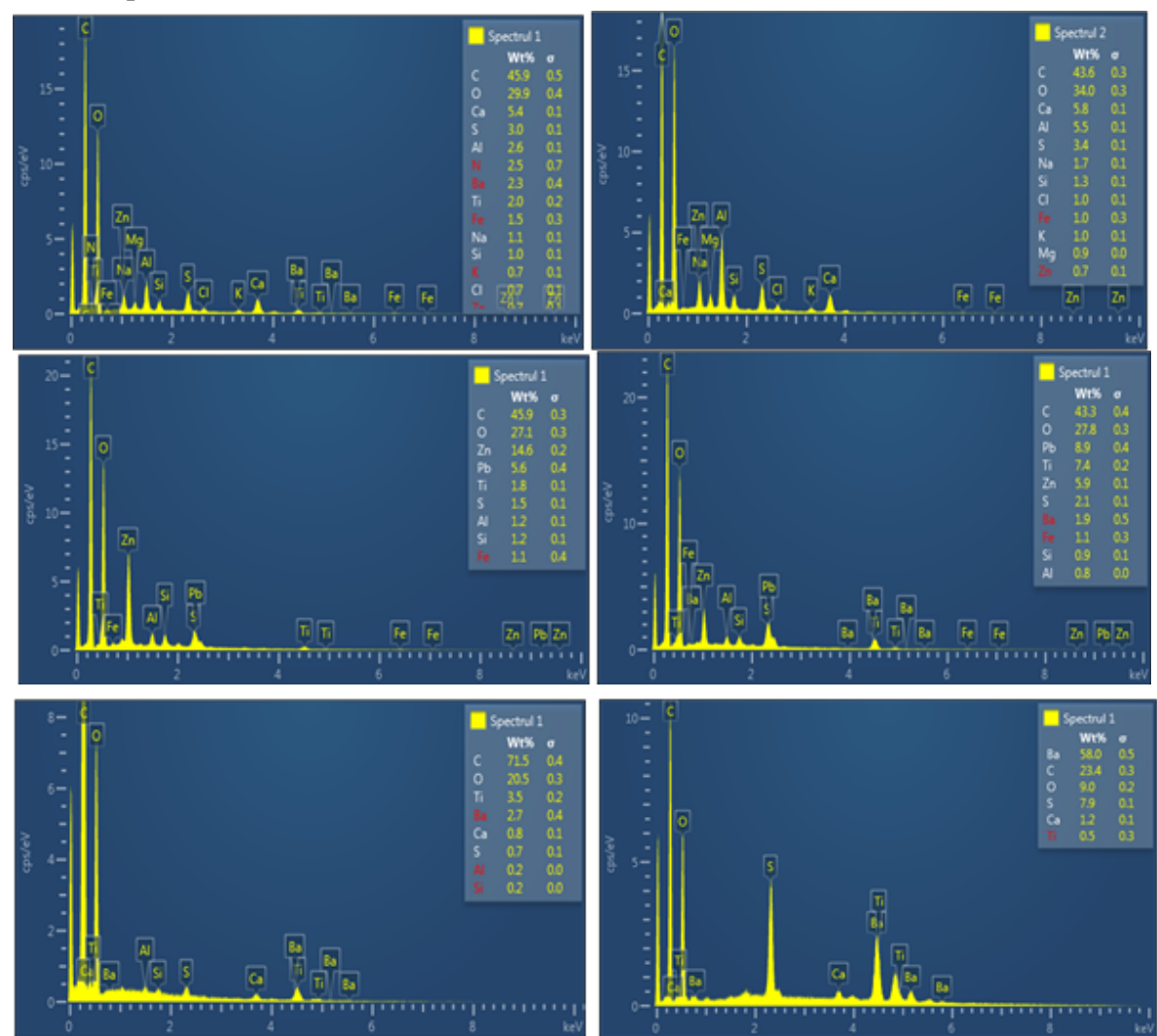

\begin{tabular}{|c|c|c|c|}
\hline \multirow{2}{*}{$\begin{array}{c}\text { Element } \\
\text { identified }\end{array}$} & \multicolumn{3}{|c|}{ Content [\%] according to location of sampling ** } \\
\cline { 2 - 4 } & $\begin{array}{c}\text { Western section } \\
\text { (painted in 2014) }\end{array}$ & $\begin{array}{c}\text { Central section (painted in } \\
\text { 1986) }\end{array}$ & $\begin{array}{c}\text { Eastern section (painted in } \\
\text { 2013) }\end{array}$ \\
\hline$C$ & 61.2 & 41.8 & 48.1 \\
\hline$O$ & 22.8 & 28.0 & 27.6 \\
\hline$B a$ & 6.5 & 0.1 & 2.3 \\
\hline$C a$ & 2.1 & 0.1 & 5.6 \\
\hline$T i$ & 3.7 & 7.5 & 1.1 \\
\hline$S$ & 3.3 & 2.1 & 3.4 \\
\hline$F e$ & - & 0.5 & 0.8 \\
\hline$Z n$ & - & 13.8 & 0.7 \\
\hline$A l$ & 0.2 & 0.5 & 2.8 \\
\hline$N$ & - & - & 2.1 \\
\hline$S r$ & - & - & 0.1 \\
\hline$C l$ & - & - & 1.1 \\
\hline$P$ & - & - & 0.2 \\
\hline$K$ & - & - & 0.9 \\
\hline$N a$ & - & - & 1.2 \\
\hline$M g$ & - & - & 0.9 \\
\hline$S i$ & 0.1 & 0.4 & 1.1 \\
\hline$P b$ & - & 5.1 & - \\
\hline
\end{tabular}

MATERIALE PLASTICE $\bullet 5$ *No. 4 \2018
Fig. 6. The representative EDAX spectra for paint samples taken from the Eastern section of bridge

Fig. 7. The representative EDAX spectra for paint samples taken from the central section of bridge

Fig. 8. The representative EDAX spectra for paint samples taken from the Western section of bridge

Table 2

COMPOSITIONS AVERAGE OF RECORDED BY EDAX SPECTRA 
Analyzing the data on the average surface composition of the investigated paint layers (table 2), it is noted that there are significant differences between the investigated paint samples.

Thus, it is noted the relatively high carbon content $(61.2$ $\%)$ in the top coat applied in 2014, compared to only $41.8 \%$ in top coat applied in 1986 and $48.1 \%$ in top coat applied in 2013 respectively. In the top coat case applied in 1986, this difference can be explained by long exposure to atmospheric weathering and to solar radiation, resulting in excessive superficial oxidation (supported by relatively high oxygen content - $28.0 \%$ ) and chalking (supported by the SEM images in fig. 4). In the top coat applied in 1986 there is a relatively high content of titanium ( $7.5 \%$ ) which suggests the use of $\mathrm{TiO}_{2}$ as an additive material which has protected the polymer against UV radiation. Thus, after 32 years of exploitation, degradation degree of the top coat applied (fig. 4) was lower than the degradations recorded in only 5.5 years in the top coat applied in 2013 (fig. 3) with a titanium content of only $1.1 \%$. It is important to note the appreciable content of chlorine, phosphorus, potassium, sodium and magnesium (the atypical paints) identified in the painting material used in 2013. The massive presence of these elements can explain both the non-uniform aspect of the surface (fig. 3 - unevenness is probably due to the dissolution of soluble compounds in the polymer composite which is mineral paint additive material), as well as the biofilm growth reported in [23].

\section{Conclusions}

In order to identify the premature biodegradation causes of paint applied in 2013 on a railway bridge by XRF and SEM-EDAX techniques after 32 years, have been investigated the top coat layers applied, exploited under identical climatic conditions for 4.5 years and 3.5 years respectively. Based on the analysis of the experimental results obtained the following aspects were observed:

- the materials and the coating system used in 1986 with lead-based primer and relatively high titanium content (7.5\%), give the first signs of aging by excessive oxidation of the polymer follow ed de chalking, only after 32 years of operation.

- the material used in 2013, after only 4.5 years of operation, has shown signs of ageing (it has both unevenness and pronounced asperities and cracks on the surface), which is explained by the relatively low content of titanium (1.1\%) and carbon (48.1\% - thus, reduced polymer weight in paint) butalso by the presence of several atypical elements for painting materials, as 1.1\% chlorine, $0.2 \%$ phosphorus, $1.2 \%$ sodium, $0.9 \%$ potassium and 0.9 $\%$ magnesium (elements which give soluble salts and are dissolved from the paint organic matrix);

- the material used in 2014 has a high content in the polymer (carbon 61.2\%) and after approx. 3.5 years of exploitation do not show signs of ageing, it has a homogeneous surface withoutunevenness and / or cracks.

In view of these findings and the fact that on materials applied in 1986 and in 2014 there are no signs of biofouling, it is considered that the massive and adherent growth of biofouling on the material used in 2013 [23] is due to both rich content in the soluble mineral salts (needed for growth and multiplication of filamentous molds) and excessive ageing of the top coat polymer.

The latter aspect, on the one hand, ensures the need necessary source for metabolisable carbon (food source for molds) and, on the other hand, pronounced cracks and unevenness that facilitate the adhesion of filaments and top coat mycelium.
Acknowledgment: The authors thank Hungarian State Railways Co. and FORKORR Ltd Hungary for access to the objective and logistical support in carrying out the work. Also thank for funding by the contract type D, no.11384/18.06.2018 (ECO-NANO-ECO)

\section{References}

1. RUS, T., BORS, A.-M., CARAMITU, A.-R., LINGVAY, I., VAIREANU, D.I., Mat. Plast., 55, no. 2, 2018, p. 167.

2. RUS, T., CARAMITU, A., MITREA, S., LINGVAY, I., Diagnostic of Electrical Machines and Insulating Systems in Electrical Engineering - DEMISEE, IEEE Xplore, 2016, p. 60.

3. YANG, X.F., TALLMAN, D.E., BIERWAGEN, G.P., CROLL, S.G., ROHLIK, S., Polymer Degradation and Stability, 77, 2002, p. 103.

4. HU, J., LI., X., GAO, J., ZHAO, Q., Materials and Design, 30, 2009, p. 1542.

5. HU, J., LI., X., GAO, J., ZHAO, Q., Progress in Organic Coatings, 65, 2009, p. 504.

6. YANG, X., LI, J., CROLL, S.G., TALLMAN, D.E., BIERWAGEN, G.P., Polymer Degradation and Stability, 65, 2003, p. 51

7. RUS, T., LINGVAY, I., CARAMITU, A.-R., BORS, A.-M., VAIREANU, D.I., Mat. Plast., 54, no.4, 2017, p. 720.

8. RUS, T., CARAMITU, A.-R., UNGUREANU, L.-C., MARINESCU, V., A.M., BORS, VAIREANU, D.-I., Mat. Plast., 55, no. 1, 2018, p. 28.

9. LINGVAY, I., UNGUREANU, L.-C., STÃNOI, V., RUS, T., BORS, A.-M., SZATMARI, I., OPRINA, G., Electrotehnica, Electronica, Automatica (EEA), 65, no.4, 2017, p. 117.

10. LINGVAY, I., RUS, T., BOR', A.-M., STANOI, V., UNGUREANU, L.-C., Electrotehnica, Electronica, Automatizari (EEA), 66, no. 3, 2018, p. 58. 11. LUNGULESCU, E.-M., LINGVAY, I., UNGUREANU, L.-C., RUS, T., BORS, A.M., Mat. Plast., 55, no. 2, 2018, p. 201.

12. LINGVAY, I., BORS, A.-M., UNGUREANU, L.-C., STANOI, V., RUS, T., Rev. Chim. (Bucharest), 69, no. 5, 2018, p. 1139.

13. GNANAVEL, G., VALLI, V.P.M.J., THIRUMARIMURUGAN, M., International J ournal of Pharmaceutical and Chemical Sciences, 1, no. 3,2012, p. 670 .

14. LOREDO-TREVINO, A., GUTIERREZ-SANCHEZ, G., RODRIGUEZHERRERA, R., AGUILAR, C.N., J. Polym. Environ., 20, 2012, p. 258.

15. LINGVAY J., GROZA C., LINGVAY C., CSUZI I., Korroz. Figy., 49, no. 30, 2009. p. 31.

16. LEJA, K., LEWANDOWICZ, G., Polish J . of Environ. Stud., 19, no. 2, 2010, p. 255.

17. RUS, T., RADU, E., LINGVAY, I., LINGVAY, M., CIOBOTEA-BARBU, O.-C., CAMPUREANU, C., BENGA F.-M., LAZAR, G.-C., VAIREANU, D.I., U.P.B. Sci. Bull., Series B, 79, no. 4, 2017. pp. 167 - 180

18. BORS, A.-M., BUTOI, N., CARAMITU, A.-R., MARINESCU, V., LINGVAY, I., Mat. Plast., 54, no.3, 2017. p. 447.

19. RAVIKUMAR, H.R., RAO, S.S., KARIGAR, C.S., Indian Journal of Science and Technology, 5, no.1, 2012, p. 1977.

20. CARAMITU, A., BUTOI, N., RUS, T., LUCHIAN, A.-M., MITREA, S., Mat. Plast, 54, no. 2, 2017, p. 331.

21. BUTOI, N., LUCHIAN, A-M., CARAMITU, A., MITREA, S., RUS, T., Electrotehnica, Electronica, Automatica (EEA), 65, no. 1, 2017, p. 72. 22. ASHWINI, R., ANCHANA DEVI, C., International J ournal of Biology Research, 3, no.1, 2018, p. 180.

23. VARGA E., FORTUNA L., LINGVAY, D., BORSA.-M., NICULA (BUTOI), N.O., LINGVAY I., Mat. Plast., 55, no. 3, 2018, p. 320.

24. NICULA (BUTOI) N.O., VARGA E., BORSA.-M., LINGVAY I., Evaluarea calitãii straturilor de vopsea. 2 - Identificarea speciilor biologice crescute pe un pod de cale feratã, Mat. Plast. 55, no. 4, 2018, p. 626 25. LINGVAY I., FORTUNA L., VARGA E., BORS A.-M., NICULA (BUTOI) N.O., LINGVAY D., Electrotehnica, Electronica, Automatica (EEA), 2018, in press

26. OPRINA G., RUS T., LINGVAY D., CARAMITU A., MITREA S., Electrotehnica, Electronica, Automatica (EEA), 65, no. 1, 2017, p. 81. 27. ROBERTSON, N., MEZZOFIORE, G., VONBERG, J.,

https://edition.cnn.com/2018/08/14/europe/italy-genoa-bridge-collapseintl/index.html 
28. LINGVAY I., VOINA A., LINGVAY C., MATEESCU C., Revue Roumaine des Sciences Techniques série Electrotechnique et energetique, 53, no. 2bis, 2008. p. 95.

29. LINGVAY, D., BORS, A.G., BOR', A.M., Electrotehnica, Electronica, Automatica (EEA), 66, no. 2, 2018, p. 5.

30. LINGVAY, I., LINGVAY, C., VOINA, A., Revue Romaine des Sciences Techniques série Électrotechnique et Energetique, 53, no. 2bis, 2008, p.85.

31. ZAKOWSKI, K., DAROWICKI, K., Polish J of Environ. Stud., 8, no. 4, 1999, p. 209.

32. MARINO A., BECKER R.O., Physiol. Chem. \& Physics, 9, 1977, p. 131.

33. SANDU D., LINGVAY I., LANYI S. MICU D.D., POPESCU C.L., BREM J., BENCZE L.C., PAIZS C., Studia Universitatis Babes-Bolyai, Chemia, LIV, no. 4, 2009. p. 195.

34. LINGVAY, M., STANCU, C., SZATMARI, I., LINGVAY, I., Electrotehnica, Electronica, Automatica (EEA), 61, no. 1, 2013. p. 43.

35. GOLTSOV, A.N., Bioelectrochem. Bioenerg., 48, 1999, p. 311.

36. HUANG, Y-J., SAMORAJ SKI, J., KREIMER, R., SEARSON, P.C., PLOS ONE, 8, no. 3, 2013, p. e59447.

37. STANCU, C., LINGVAY, M., SZATMARI, I., LINGVAY, I., The 8th International Symposium on Advanced Topics in Electrical Engineering, Bucharest, 2013, p. 1.

38. RADU, E., LIPCINSKI, D., TANASE, N., LINGVAY, I., Electrotehnica, Electronica, Automatizari, (EEA), 63, no. 3, 2015, p. 68.

39. SZATMARI, I., LINGVAY, M., TUDOSIE, L., COJ OCARU, A., LINGVAY, I., Rev. Chim. (Bucharest), 66, no. 3, 2015, p. 304.

40. LINGVAY J., SZATMARI I., LINGVAY M., TUDOSIE L., Korroz. Figy., LIII, no 3, 2013. p. 71.
41. LINGVAY, J., SZATMARI, I., PRIOTEASA, P., LINGVAY, M., TUDOSIE, L. M., Korroz. Figy., LIV, no. 1, 2014, p. 15.

42. LINGVAY, J, RADU E., MITREA S., LINGVAY M., UDREA O., SZATMARI I., Korroz. Figy., LIV no. 2, 2014, p. 40.

43. SZATMARI, I., TUDOSIE, L.M., COJOCARU, A., LINGVAY, M., PRIOTEASA, P., VISAN, T., U.P.B. Sci. Bull., Series B, 77, no. 3, 2015, p. 91.

44. LINGVAY, I., RUS, G., STOIAN, F., LINGVAY, C., UPB Sci. Bull, Series B, 63, no. 3, 2001, p. 263.

45. LINGVAY, I., RUS, G., BURUNTEA, N., UPB Sci. Bull, Series B, 63 , no. 3, 2001, p. 29.

46. LINGVAY, I., OLLERER, K., LINGVAY, C., HOMAN, C., CIOGESCU, O., Rev. Chim., (Bucharest), 58, no. 7, 2007, p. 624.

47. PRIOTEASA, P., LINGVAY, M., SZATMARI, I., BURUNTEA, N., LINGVAY, I., Electrotehnica, Electronica, Automatica (EEA), 62, no. 2, 2014, p. 60.

48. RADU, E., MITREA, S., UDREA, O., PATROI, D., MARIN, D., Electrotehnica, Electronica, Automatica (EEA), 63, no. 2, 2015, p. 110. 49. NEAMTU, S., BORS, A.-M., STEFAN, S., Rev. Chim. (Bucharest), 58 no. 9, 2007. p. 938.

50. BORS, A.M., MEGHEA, A. ESEANU D., NEAMTU, S., LESNIC M., Rev. Chim. (Bucharest), 58, no. 8, 2007, p. 776.

51. BORS, A.M., MEGHEA, I., NICOLESCU, A.M., BORS, A.-G., 12h International Multidisciplinary Scientific Geoconference (SGEM), Albena, Bulgaria, V, 2012, p. 891.

$\overline{\text { Manuscript received: } 18.09 .2018}$ 